PRIMER NOTE

\title{
Isolation and characterization of microsatellite DNA markers from the Lanyu scops owl (Otus elegans botelensis)
}

\author{
YU-CHENG HSU, *+ LUCIA L. SEVERINGHAUS, $\ddagger$ YAO-SUNG LIN* and SHOU-HSIEN LI§ \\ *Laboratory of Biodiversity, Institute of Zoology, National Taiwan University, Taipei 106 Taiwan, ROC; †Laboratory of Ornithology, \\ Institute of Zoology, Academia Sinica, Taipei 115 Taiwan, ROC; §Laboratory of Genetic Diversity, Department of Biology, National \\ Taiwan Normal University, Taipei 116 Taiwan, ROC
}

\begin{abstract}
From a genomic library enriched for GATA/CTAT and GAAA/CTTT repeats, 12 polymorphic microsatellite markers were developed for the Lanyu scops owl (Otus elegans botelensis). Polymorphism of these loci was evaluated in a sample of 58 adult individuals of unknown relationship. The allele numbers of each locus were from five to 25 and the observed heterozygosity of each locus ranges from 0.707 to 0.914 . When using these loci in parentage assignment, the probability of false parent exclusion is greater than 0.999 . All loci conformed to Hardy-Weinberg expectations.
\end{abstract}

Keywords: Otus elegans botelensis, Lanyu scops owl, microsatellites, strigidae, enrichment, genotyping

Received 18 June 2003; revision received 12 August 2003; accepted 12 August 2003

Lanyu scops owl (Otus elegans botelensis) is a subspecies of elegant scops owl (O.elegans) and was listed as endangered in the Red Data Book (King 1981). It is found only on Lanyu Island $\left(22^{\circ} \mathrm{N}, 121^{\circ} 5^{\prime}-\mathrm{E}\right)$, a $45.7-\mathrm{km}^{2}$ island $60 \mathrm{~km}$ southeast of Taiwan. A long-term study on the behaviour, ecology and population dynamics of this species has been conducted since 1985 (e.g. Severinghaus 2000; Severinghaus \& Rothery 2001) making it one of the few tropical owl species intensively studied. Extra-pair copulations were observed occasionally during the breeding season (Severinghaus, personal observation). To further investigate the population structure and genetic mating system of this species, highly polymorphic genetic markers, such as microsatellites, are needed. In this study, we constructed a microsatellite-enriched genomic DNA library of Lanyu scops owl to screen for highly polymorphic microsatellite DNA loci.

Genomic DNA from an adult owl was used to construct a library. After digestion with HaeIII, RsaI and AluI restriction enzymes, the fragments were ligated with SNX linker (Hamilton et al. 1999). These ligates were first amplified using polymerase chain reaction (PCR) at $94^{\circ} \mathrm{C}$ for $5 \mathrm{~min}$, 30 cycles of $94^{\circ} \mathrm{C}$ for $1 \mathrm{~min}, 55^{\circ} \mathrm{C}$ for $1 \mathrm{~min}$, and $70{ }^{\circ} \mathrm{C}$ for

Correspondence: Shou-Hsien Li. tPresent address: Department of Biology, National Taiwan Normal University, Taipei 116 Taiwan, ROC. Fax: 886-2-29312904; E-mail: t43028@cc.ntnu.edu.tw
2 min then $70{ }^{\circ} \mathrm{C} 5 \mathrm{~min}$, followed by a solid phase hybridization with $3^{\prime}$-biotin-labelled (GAAA) ${ }_{10}$ or (GATA) ${ }_{10}$ oligonucleotides to select for microsatellite-containing DNA fragments. The biotin-labelled DNAs were eluted using Dynalbead streptavidin M280 (Dynal®) according to the manufacturer's instruction. These microsatellite-enriched DNAs were PCR-amplified (Li et al. 1997) then ligated into vectors and transformed to JM109 competent cells, using pGEM®-T Easy vector system II (Promega). Transformed cells were grown on LB agar plates containing ampicillin, X-gal and IPTG for blue/white selection of positive clones at $37{ }^{\circ} \mathrm{C}$ for $16 \mathrm{~h}$. A total of 1500 positive clones were lifted to Hybond-N+ membranes (Amersham Pharmacia Biotech) and hybridized with [r32P] ATP end-labelled (GAAA) ${ }_{8}$ or (GATA) ${ }_{8}$ oliginucleotides, then 192 positive inserts were selected to extract their plasmid DNA, using the Montage Plasmid Miniprep kit (Millipore). These plasmid DNAs were sequenced using DYEnamic ET Dye Terminator Cycle Sequencing Kit for MegaBACE on MegaBACE 1000 autosequencer (Amersham Bioscience). Sequences were edited in SEQUENCHER software (V4.0.5, Gene Codes corporation) and 22 primer pairs were designed from 54 sequences containing tandem repeats and suitable flanking sequences, using FASTPCR 2.3.10 program which is available at http://www.biocentre.helsinki.fi/bi/bare1_html/download.htm. 
Table 1 Characterization of 12 microsatellite loci in the Lanyu scops owls

\begin{tabular}{|c|c|c|c|c|c|c|c|c|c|c|c|}
\hline Locus & Repeat motif & Primer sequences $\left(5^{\prime}-3^{\prime}\right)$ & $\begin{array}{l}\text { Size of } \\
\text { cloned } \\
\text { allele }\end{array}$ & $\begin{array}{l}\text { No. of } \\
\text { alleles }\end{array}$ & $T_{\mathrm{a}}\left({ }^{\circ} \mathrm{C}\right)$ & $\mathrm{MgCl}_{2}(\mathrm{mM})$ & $H_{\mathrm{O}}$ & $H_{\mathrm{E}}$ & $P(E)(1)$ & $P(E)(2)$ & $\begin{array}{l}\text { GenBank } \\
\text { accession } \\
\text { no. }\end{array}$ \\
\hline Oe3-7 & $(\mathrm{GATA})_{12}$ & $\begin{array}{l}\text { F-GTGGGTTTATTGCCCCCTCG } \\
\text { R-CAGATGAATGAATGGATAGATGG }\end{array}$ & 121 & 7 & 52 & 2.0 & 0.776 & 0.765 & 0.367 & 0.545 & AY312418 \\
\hline Oe3-21 & $(\text { GATA })_{15}$ & $\begin{array}{l}\text { F-GATTAGAGACCCGATTCCACA } \\
\text { R-TTATCTGAGTGGAAGGGTAGTGC }\end{array}$ & 139 & 5 & 52 & 2.0 & 0.845 & 0.741 & 0.326 & 0.501 & AY312419 \\
\hline Oe2-57 & $(\mathrm{GAAA})_{19}$ & $\begin{array}{l}\text { F-TTTATCTTGTATTTTTCATCACTG } \\
\text { R-ССАACTAAАСАСТАTCTTTCTCC }\end{array}$ & 197 & 25 & 55 & 1.5 & 0.914 & 0.899 & 0.647 & 0.785 & AY312420 \\
\hline Oe022 & $(\mathrm{GATA})_{12}$ & $\begin{array}{l}\mathrm{F}^{\prime} \text {-АTCTGATTCAGTGTCTCCATCCATG } \\
\mathrm{R}^{\prime} \text {-CCCAGGAATCTCTCCCAATGTT }\end{array}$ & 260 & 6 & 64 & 2.5 & 0.741 & 0.725 & 0.579 & 0.736 & AY312421 \\
\hline Oe045 & $(\mathrm{GATA})_{13}$ GATTA $(\mathrm{GATA})_{10}$ & $\begin{array}{l}\text { F-GTATGTTCTACGTTGGATTTCCA } \\
\text { R-AAACCTGGCAAGTGCTGTT }\end{array}$ & 181 & 16 & 58 & 2.5 & 0.845 & 0.830 & 0.237 & 0.411 & AY312422 \\
\hline Oe050 & $(\text { GATA })_{11}$ & $\begin{array}{l}\text { F-AGAGTTGTCCTTGGTTGG } \\
\text { R-TTCTAGTAACCTCATCTGC }\end{array}$ & 136 & 12 & 57 & 2.5 & 0.862 & 0.874 & 0.308 & 0.484 & AY312423 \\
\hline Oe053 & $(\mathrm{GATA})_{13}$ & 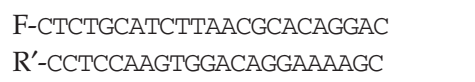 & 181 & 7 & 64 & 2.5 & 0.707 & 0.645 & 0.631 & 0.774 & AY312424 \\
\hline Oe054 & $(\text { GATA })_{10}$ & $\begin{array}{l}\text { F-TCAGAAAGAAAACTTCAGCAACC } \\
\text { R-CATATATGTATACACAGGCACATGC }\end{array}$ & 256 & 20 & 64 & 2.5 & 0.828 & 0.869 & 0.332 & 0.515 & AY312425 \\
\hline Oe092 & $\begin{array}{l}(\text { GATA })_{12} \text { GAAGGAAAGATA } \\
\text { GAT(GATA })_{9} \text { AATA }(\text { GATA })_{3}\end{array}$ & $\begin{array}{l}\text { F-CTCACTGCCTCTGAGCAGAAG } \\
\text { R-AGCCAAGGTCAAACCACCAC }\end{array}$ & 233 & 14 & 65 & 1.5 & 0.828 & 0.894 & 0.507 & 0.678 & AY312426 \\
\hline Oe128 & $(\mathrm{GATA})_{13}$ & $\begin{array}{l}\mathrm{F}^{\prime} \text {-CGTTGTAAATGATGAATCGCCTAGTGC } \\
\mathrm{R}^{\prime} \text {-ATGCATGTATACATACAAACCTGG }\end{array}$ & 297 & 8 & 64 & 2.5 & 0.759 & 0.735 & 0.585 & 0.739 & AY312427 \\
\hline Oe142 & $(\text { GATA })_{14}$ & $\begin{array}{l}\text { F-TGAATCAGCAAACCTGTGCCTG } \\
\text { R-AGCTAACCTAGAGTCAGCCAGC }\end{array}$ & 293 & 7 & 65 & 2.0 & 0.810 & 0.808 & 0.429 & 0.606 & AY312428 \\
\hline Oe171 & $(\text { GATA })_{12}$ & $\begin{array}{l}\text { F-TTTTACAAACTACTAGTGCATGTCTCC } \\
\text { R-AGATGTTGTATTTCAGTGTCAG }\end{array}$ & 245 & 7 & 64 & 2.5 & 0.776 & 0.782 & 0.389 & 0.568 & AY312429 \\
\hline Overall & & - & - & - & - & - & 0.808 & 0.797 & 0.999412 & 0.999994 & \\
\hline
\end{tabular}

$T_{\mathrm{a}}$ : annealing temperature; $H_{\mathrm{O}}$ : observed heterozygosity; $H_{\mathrm{E}}$ : expected heterozygosity; $\mathrm{P}(\mathrm{E})(1)$ : exclusionary power of false parent when neither parent is unknown; $\mathrm{P}(\mathrm{E})(2)$ : exclusionary power of false parent when one parent is known. 
Nineteen of the primer pairs showed a PCR product with expected sizes and 12 of them were selected to screen for polymorphism. The forward primers of these 12 loci were labelled with HEX, FAM or TAMRA fluorescent dyes. For the characterization of polymorphism of these loci, 58 adult individuals with unknown relationship were genotyped. PCR were set up in $10 \mu \mathrm{L}$ reaction volume containing $30 \mathrm{ng}$ genomic DNA, $0.3 \mu \mathrm{M}$ each primer, $0.5 \mathrm{~mm}$ dNTP, 10 mm Tris-HCL, pH 9.0, 50 mm KCL, 0.01\% (w/V) gelatin, $0.1 \%$ Triton X-100, $0.4 \mathrm{U}$ Pro Taq DNA polymerase (Protech) and 1.5-2.5 mM $\mathrm{MgCl}_{2}$ (see Table 1). The PCR condition was as follows: Firstly, denaturation at $94{ }^{\circ} \mathrm{C}$ for $3 \mathrm{~min}$, then 34 cycles of $94^{\circ} \mathrm{C} 30 \mathrm{~s}, 30 \mathrm{~s}$ at the optimal annealing temperature of each primer pair (Table 1) and $72{ }^{\circ} \mathrm{C}$ for $30 \mathrm{~s}$, followed by a final extension at $72{ }^{\circ} \mathrm{C}$ for $3 \mathrm{~min}$. All of the PCR in this study were conducted using iCycler thermal cycler (Bio-Rad). The PCR products were electrophoresed in MEGABACE 1000 autosequencer (Amersham Biosciences). Sizing of alleles was analysed with the software GENETIC PROFLIER 2.0 (Amersham Biosciences).

Table 1 summarized the polymorphism of the 12 microsatellite loci. The observed and expected heterozygosities, probability of false parent exclusion and conformation to Hardy-Weinberg expectations were calculated using program CERVus 2.0 (Marshall et al. 1998). No significant deviation from Hardy-Weinberg equilibrium was detected across all loci. Overall, the mean number of alleles per locus was 11.17 and the mean expected heterozygosity was 0.797. When applying these loci to paternity analysis, more than $99.9 \%$ of false putative parents can be excluded. The highly polymorphic nature of these microsatellite loci makes it an ideal genetic marker system to study the population genetics and mating system of the Lanyu scops owl.

\section{Acknowledgements}

This work was funded by the National Science Council to LLS (NSC 90-2313-B-001-036) and by the Council of Agriculture to SHL [COA 90AT-1.3.3-F-R1(5)]. We thank Dr Y. J. Huang and members of Genetic Diversity Laboratory for the help in lab work and all assistants of Ornithology Laboratory for collecting blood samples.

\section{References}

Hamilton MB, Pincus EL, Fiore AD, Fleischer RC (1999) Universal linker and ligation procedures for construction of genomic DNA libraries enriched for microsatellites. Biotechniques, 27, 500-507. King WB (1981) Endangered Birds of the World. The ICBP Bird Red Data Book. Smithsonian Institute Press, Washington, DC.

Li SH, Huang YJ, Brown JL (1997) Isolation of tetranucleotide microsatellites from the Mexican Jay Aphelocoma ultramarina. Molecular Ecology, 6, 499-501.

Marshall TC, Slate J, Kruuk LEB, Pemberton JM (1998) Statistical confidence for likelihood-based paternity inference in natural populations. Molecular Ecology, 7, 639-655.

Severinghaus LL (2000) Territoriality and the significance of calling in the Lanyu scops owl. Otus Elegans Botelensis. IBIS, 142, 297-304.

Severinghaus LL, Rothery P (2001) The survival rate of Lanyu scops owls. Otus Elegans Botelensis. IBIS, 143, 540-546. 